\title{
Vegetation Structure of Ebony Leaf Monkey (Trachypithecus auratus) Habitat in Kecubung Ulolanang Nature Preservation Central Java-Indonesia
}

\author{
Rahmawati Ervina ${ }^{1, *}$, Hidayat Jafron Wasiq ${ }^{2}$ \\ ${ }^{1}$ Master Program of Environmental Science, School of Postgraduate Studies, Diponegoro Univers ity, Semarang - Indonesia \\ ${ }^{2}$ Department of Biology, Faculty of Mathematics and Science, Diponegoro University, Semarang - Indonesia
}

\begin{abstract}
Kecubung Ulolanang Nature Preservation is ebony leaf monkey's habitats in Central Java Indonesia. Continuously degradation of their population is caused by illegal hunting and habitat degradation that made this species being vulnerable. Habitat conservation is one of important aspects to prevent them from extinction. The purpose of this research was to analyze the vegetation's structure and composition, which was potentially, becomes habitat and food source for the monkeys. Data collected using purposive sampling with line transect method of four different level of vegetation. Data analys is used Important Value Index and Diversity Index. There were 43 species of vegetation at seedling stage, 18 species at sapling stage, 8 species at poles stage and 27 species at trees stage. Species that had the highest important value index at seedling was Stenochlaena palustri, at the sapling was Gnetum gnemon, at pole was Swietenia mahagoni and at tree was Tectona grandis. Species of trees those were potentially to become habitat (food source) for ebony leaf monkey were T. grandis, Dipterocarpus gracilis, Quercus sundaica and Ficus superba. The highest diversity index was at seedling gwoth stage.
\end{abstract}

\section{Introduction}

Extinction threat of wild plants and animals which was occurred naturally or caused by over exploitation becomes a necessary issue about environment. Human population growth and development in many sectors have been cause a narrowing animal space-range, decreasing quality and fragmentation of animal habitat.

Ebony leaf monkey (Trachypitecus auratus) is an endemic species of Java, Bali and Lombok Island [1]. Nowadays, ebony leaf monkeys have an conservation status vulnerable from IUCN [1,2], because of their decreased as an effect to illegal hunting and habitat degradation [3], so they need conservation action as soon as possible [4]. Such decrease and population change were not only in java, but also in Bali (Leca, et al., 2013) [5].

According to Gunawan et al. [6], Central Java Province had lost its dry land natural forest about $446.561,09$ hectares or $88 \%$ for duration of 16 years (1990-2006). The remains of dry land natural forest usually left on mountain peaks which are hardly touched by human activities. Further, according to [6], natural forest fragmentation in Central Java which were occurred among 1990 - 2000 made a total edge (TE) increasing from $42,43 \mathrm{~km}$ to $133,88 \mathrm{~km}$, usually caused by forest conversion to farmland, man-made forest, plantation, settlement area and infrastructure development (artery road, highway and high tension transmission lines (SUTET)).
To conserve habitat and the species of ebony leaf monkey, it has to do in-situ and ex-situ conservation actions. Habitat conservation is important to prevent the extinction of this species. Kecubung Ulolanang Nature Preservation is a lowland rainforest type with high biodiversity and becomes an in-situ habitat of ebony leaf monkeys [7]. To understand about habitat condition, it is need data about its vegetation structure because ebony leaf monkeys use the trees for providing their food and their nest. Ebony leaf monkeys choose their own trees for food; vegetation structure of ebony leaf monkeys' habitat can be identified from the vegetation data i.e. seedling, sapling, pole and tree of four growth stage.

The purpose of this research was to analyze the vegetation's structure and composition, which was potentially, becomes habitat and food source for the ebony leaf monkey.

\section{Method}

\subsection{Study Area}

The study was conducted in Kecubung Ulolanang Nature Preservation Batang (6 $51^{\prime} 46^{\prime \prime}-7^{\circ} 11^{\prime} 43^{\prime \prime} \mathrm{N}$ and $109^{\circ} 40^{\prime} 19^{\prime \prime}-110^{\circ} 03^{\prime} 06^{\prime \prime}$ E) Central Java Indonesia.

Kecubung Ulolanang Nature Preservation as a nature preserve based on Ministerial Decree of Forestry and Plantation no. 435 / Kpts-II / 1999 dated June 15, 1999. The topography of the area was hillary with long slopes to the south, with a river that is use as a source of water for the surrounding community and a natural boundary 
for this region. The area is located at 165 meters above sea level with temperature minimum $24.4{ }^{\circ} \mathrm{C}$ and maximum $29^{\circ} \mathrm{C}$, and annual precipitation of $277.7 \mathrm{~mm}$. In addition, the soil classified as latosol developed from felsic igneous rock and intermediary.

\subsection{Material and Method}

In this study, data was collected in April to May 2017 using survey and observation method. Vegetation sample were accumulated through purposive sampling with line transect method on the habitat of ebony leaf monkey. In this method the plot were taken at four growth stage, i.e. $2 \times 2 \mathrm{~m}$ for seedling, $5 \times 5 \mathrm{~m}$ for sapling, $10 \times 10 \mathrm{~m}$ for poles and $20 \times 20 \mathrm{~m}$ for trees. Total plots area for seedling level was $96 \mathrm{~m}^{2}$, at sapling level was $600 \mathrm{~m}^{2}$, then $2,400 \mathrm{~m}^{2}$ at poles level and at tress level was 9,600 $\mathrm{m}^{2}$.

Seedling are categorized from sprout to young of 1.5 $\mathrm{m}$ including herbs and shrubs. Furthermore, sapling are plants with DBH of less $10 \mathrm{~cm}$ and higher than $1.5 \mathrm{~m}$, then Poles are plants with DBH between $10-20 \mathrm{~cm}$, and trees are plant with DBH more than $20 \mathrm{~cm}$ [8]. Each plot $(20 \mathrm{~m} \times 20 \mathrm{~m})$ was repeated 3 times, located in eight different places.

\subsection{Data Analysis}

In this study focused on the vegetation areas that became the habitat of Ebony Leaf Monkey. Community struct including diversity and important value of vegetations.

It was quantified relative density, relative frequency, relative dominance, and importance value index (IVI) for all species following Dombois, et al. (1974) [9]. To determine species diversity, we use the Shannon-Wiener index. The formula for diversity index and important value index are presented below.

$$
\begin{aligned}
\ldots . \mathrm{RDi} & =\frac{\text { Density of a species }}{\text { Total density of all species }} \times 100 \\
\ldots . \mathrm{RF} & =\frac{\text { Frequency of a species }}{\text { Total frequency of all species }} \times 100 \\
\ldots . \mathrm{RDo} & =\frac{\text { Dominance of a species }}{\text { Total dominance of all species }} \times 100 \\
\ldots . . . \mathrm{Di} & =\frac{\text { Number of a species }}{\text { Total area sampled }} \text { X } 100 \\
\ldots . \mathrm{Do} & =\frac{\text { Trea of a plot in which a species accours }}{\text { Total area sampled }}
\end{aligned}
$$

\section{Result}

\subsection{Species Abundance and Diversity}

Observation result revealed total 978 individuals

\begin{tabular}{|c|c|c|c|c|c|c|}
\hline $\begin{array}{l}\text { Growth } \\
\text { Stage }\end{array}$ & Species & Family & $\mathbf{N i}$ & Species & Family & $\mathbf{N i}$ \\
\hline Seedling & $\begin{array}{l}\text { Achasma coccineum } \\
\text { Ageratum conyzoides } \\
\text { Aglaia odoratissima } \\
\text { Caesalpinia sappan } \\
\text { Calamus sp } \\
\text { Chloranthus officinale } \\
\text { Coffea sp } \\
\text { Commelina nudiflora } \\
\text { Corypa utan } \\
\text { Costus speciosus } \\
\text { Cyclea barbata } \\
\text { Dalbergia latifolia } \\
\text { Dioscorea hispida } \\
\text { Dipterocarpus geacilis } \\
\text { Donax canniformis } \\
\text { Erioglossum rubiginosum } \\
\text { Eugenia polyantha } \\
\text { Euphatorium odoratum } \\
\text { Ficus hispida } \\
\text { Flagellaria indica } \\
\text { Garcinia sp } \\
\text { Globba marantina }\end{array}$ & $\begin{array}{l}\text { Zingiberaceae } \\
\text { Asteraceae } \\
\text { Meliaceae } \\
\text { Fabaceae } \\
\text { Arecaceae } \\
\text { Chloranthaceae } \\
\text { Rubiaceae } \\
\text { Commelinaceae } \\
\text { Arecaceae } \\
\text { Costaceae } \\
\text { Menispermaceae } \\
\text { Fabaceae } \\
\text { Dioscoreaceae } \\
\text { Dipterocarpaceae } \\
\text { Marantaceae } \\
\text { Sapindaceae } \\
\text { Myrtaceae } \\
\text { Asteraceae } \\
\text { Moraceae } \\
\text { Flagellariaceae } \\
\text { Clusiaceae } \\
\text { Zingiberaceae }\end{array}$ & $\begin{array}{l}16 \\
69 \\
10 \\
2 \\
5 \\
4 \\
2 \\
30 \\
1 \\
24 \\
13 \\
4 \\
8 \\
22 \\
17 \\
1 \\
2 \\
19 \\
1 \\
9 \\
2 \\
26\end{array}$ & $\begin{array}{l}\text { Grewia panicuta } \\
\text { Imperata cylindrica } \\
\text { Lantana camara } \\
\text { Leea indica } \\
\text { Leersia hexandra } \\
\text { Mallotus paniculatus } \\
\text { Mimusops elengi } \\
\text { Nephelium lappaceum } \\
\text { Pandanus sp } \\
\text { Piper baccatum } \\
\text { Piper cubeba } \\
\text { Prema integrifolia } \\
\text { Quercus sundaica } \\
\text { Stachytarpheta jamaicensis } \\
\text { Stenochlaena polustris } \\
\text { Streblus asper } \\
\text { Tetracera scandens } \\
\text { Tridax procumbens } \\
\text { Urena lobata } \\
\text { Xanthophyllus excelsum } \\
\text { Krotak }\end{array}$ & $\begin{array}{l}\text { Malvaceae } \\
\text { Poaceae } \\
\text { Verbenaceae } \\
\text { Leeaceae } \\
\text { Poaceas } \\
\text { Euphorbiaceae } \\
\text { Sapotaceae } \\
\text { Sapindaceae } \\
\text { Pandanaceae } \\
\text { Piperaceae } \\
\text { Piperaceae } \\
\text { Verbenaceae } \\
\text { Fagaceae } \\
\text { Verbenaceae } \\
\text { Blechnaceae } \\
\text { Moraceae } \\
\text { Dilleniaceae } \\
\text { Asteraceae } \\
\text { Malvaceae } \\
\text { Polygalaceae }\end{array}$ & $\begin{array}{l}27 \\
34 \\
32 \\
11 \\
7 \\
12 \\
4 \\
3 \\
20 \\
12 \\
22 \\
27 \\
4 \\
18 \\
116 \\
5 \\
41 \\
6 \\
66 \\
8 \\
10\end{array}$ \\
\hline $\begin{array}{l}\text { Growth } \\
\text { Stage }\end{array}$ & Species & Family & $\mathrm{Ni}$ & Species & Family & $\mathrm{Ni}$ \\
\hline Sapling & $\begin{array}{l}\text { Artocarpus elastica } \\
\text { Coffea sp } 4\end{array}$ & $\begin{array}{l}\text { Moraceae } \\
\text { Rubiaceae }\end{array}$ & $\begin{array}{l}1 \\
1\end{array}$ & $\begin{array}{l}\text { Leea indica } \\
\text { Mallotus paniculatus }\end{array}$ & $\begin{array}{l}\text { Leeaceae } \\
\text { Euphorbiaceae }\end{array}$ & $\begin{array}{l}5 \\
1\end{array}$ \\
\hline
\end{tabular}
belonging to 68 species and 33 families of growth stage was reported in the 24 plots. There were 43 species at seedling stage, then 18 species at sapling stage, 8 species at poles stage and 27 species at trees stage. Species abundance at growth stage present at Table.1 below.

Table.1. Species abundance at growth stage. 


\begin{tabular}{|c|c|c|c|c|c|c|}
\hline $\begin{array}{c}\text { Growth } \\
\text { Stage }\end{array}$ & Species & Family & $\mathbf{N i}$ & Species & Family & $\mathbf{N i}$ \\
\hline & Dipterocarpus gracilis & Dipterocarpaceae & 3 & Nephelium lappaceum & Sapindaceae & 1 \\
\hline & Erioglossum rubiginosum & Sapindaceae & 1 & Pithecolobium lobatum & Fabaceae & 1 \\
\hline & Garcinia $s p$ & Clusiaceae & 1 & Quercus sundaica & Fagaceae & 1 \\
\hline & Gluta renghas & Anacard iacea & 1 & Streblus asper & Moraceae & 1 \\
\hline & Gnetum gnemon & Gnetaceae & 3 & Swietenia mahagony & Meliaceae & 1 \\
\hline & Grewia paniculata & Malvaceae & 5 & Syzygium densiflora & Myrtaceae & 1 \\
\hline & Hibiscus tiliaceus & Malvaceae & & Tectona grandis & Verbenaceae & 1 \\
\hline \multirow[t]{4}{*}{ Poles } & Albizzia procera & Fabaceae & 1 & Nephelium lappaceum & Sapindaceae & 1 \\
\hline & Erioglossum rubiginosum & Sapindaceae & 1 & Pithecolobium lobatum & Fabaceae & 1 \\
\hline & Gnetum gnemon & Gnetaceae & 2 & Swietenia mahagony & Meliaceae & 2 \\
\hline & Mallotus paniculatus & Euphorbiaceae & 1 & Tectona grandis & Verbenaceae & 1 \\
\hline \multirow[t]{14}{*}{ Trees } & Albizzia chinensis & Fabaceae & 1 & Ficus superba & Moraceae & 3 \\
\hline & Albizzia procera & Fabaceae & 10 & Gluta renghas & Anacard iacea & 1 \\
\hline & Anacardium occidentale & Anacard iacea & 1 & Gnetum gnemon & Gnetaceae & 1 \\
\hline & Artocarpus elastica & Moraceae & 1 & Mallotus paniculatus & Euphorbiaceae & 1 \\
\hline & Artocarpus integra & Moraceae & 1 & Nephelium mutabile & Sapindaceae & 1 \\
\hline & Bambusa sp. & Poaceae & 21 & Otophora spectabilis & Sapindaceae & 1 \\
\hline & Barringtonia racemosa & Lecythidaceae & 1 & Pangium edule & Achariaceae & 1 \\
\hline & Calamus sp. & Arecaceae & 26 & Planchonella nitida & Sapotaceae & 1 \\
\hline & Cocos nucifera & Arecaceae & 1 & Quercus sundaica & Fagaceae & 16 \\
\hline & Corypa utan & Arecaceae & 1 & Salacca edulis & Arecaceae & 13 \\
\hline & Dipterocarpus gracilis & Dipterocarpaceae & 14 & Swietenia mahagony & Meliaceae & 13 \\
\hline & Dracontomelon dao & Anacard iacea & 1 & Tectona grandis & Verbenaceae & 18 \\
\hline & Enterolobium cyclocarpum & Fabaceae & 3 & Toona sureni & Meliaceae & 1 \\
\hline & Eugenia polvantha & Myrtaceae & 1 & & & \\
\hline
\end{tabular}

$\mathrm{Ni}$ is the number of individuals.

The abundance and Diversity Index were present in Table.1 below. Diversity Index (H') at seedling was highest than other growth stage. Accordingly to the diversity index value, the species abundance of seedling stage was highest than sapling, poles and trees stage [5]. It's because many species at seedling stage include herbs and shrubs besides seedling trees could be found in the plot areas.

The highest diversity index value at seedling level i.e. 3.24, it's means that the diversity was abundant, so do of tree level of 3. 2. Furthermore, at sapling and pole stage the diversity index were lower at 2.64 and 2.02 respectively, indicated that the diversity was average. For details can be seen at Table. 2 .

Table.2. The abundance and Species Diversity at Renegeration Level in Kecubung Ulolanang Nature Preservation Central Java Indonesia.

\begin{tabular}{lcccc}
\hline & Seedling & Sapling & Poles & Trees \\
\hline $\mathrm{N}$ & 772 & 32 & 10 & 155 \\
$\mathrm{~S}$ & 43 & 18 & 8 & 27 \\
$\mathrm{H}$ & 3.24 & 2.64 & 2.02 & 3.2 \\
$\mathrm{D}\left(\right.$ ind $\mathrm{ha}^{-1}$ ) & 80 & 533 & 42 & 161 \\
\hline
\end{tabular}

$\mathrm{N}$ is the number individuals registered. $\mathrm{S}$ is the total number of species censuses. H' is the Shannon- Wiener diversity index,. $\mathrm{D}$ is the number of density (ind ha ${ }^{-1}$ ).

\subsubsection{Seedling}

Based on inventory vegetation's result, there were 43 species of 772 individual including trees and shrubs at seedling stage. The highest species density was Stenochlaena polustris at 12 ind ha $^{-1}$, whereas Corypha utan, Erioglossum rubiginosum and Ficus hispida had the lowest species density at 104.16 in $^{-1}{ }^{-1}$. Likewise, the species with the highest relative density and relative frequency was Stenochlaena polustris. It was the important species at seedling level with the highest IVI at $22.85 \%$. The Important Value Index at seedling and sapling level were present in Table. 3 below.

Table.3. Important Value Index (IVI) at Seedling and Sapling Level.

\begin{tabular}{lccc}
\hline (A) $\quad$ Species & $\begin{array}{c}\text { Relative } \\
\text { Density } \\
(\%)\end{array}$ & $\begin{array}{c}\text { Relative } \\
\text { Frequency } \\
(\%)\end{array}$ & IVI (\%) \\
\hline Stenochlaena polustris & 15.02 & 7.82 & 22.85 \\
Urena lobata & 8.94 & 7.82 & 16.76 \\
Ageratum conyzoides & 8.55 & 5.22 & 13.77 \\
\hline (B) Species & Relative & Relative \\
& Density & Frequency & IVI (\%) \\
& $(\%)$ & $(\%)$ & \\
\hline Gnetum gnemon & 12.50 & 14.81 & 27.31 \\
Grewia paniculata & 15.62 & 11.11 & 26.73 \\
Leea indica & 15.62 & 11.11 & 26.73 \\
\hline
\end{tabular}

(A) is at seedling level, (B) is at sapling level. IVI = relative density + relative frequency.

Herbs and shrubs at this growth stage were found abundant rather tree seedlings. Even they s on the bottom rank i.e. E. rubiginosum and F. hispida.

\subsubsection{Sapling}

There were 18 species of 32 individuals at sapling level. The species which the highest relative density and relative frequency and also the most important species with the highest IVI was Gnetum gnemon at $27.31 \%$ 
(presented in Table.2). It's had the species density at 67 ind $\mathrm{ha}^{-1}$, less than Grewia paniculata and Leea indica, but it's had relative frequency higher than both at $16.67 \%$. Not all species could be found at seedling stage also found at sapling stage. It was because spatial competition.

\subsubsection{Poles}

The inventory's result there were 8 species of 10 individuals at poles level. Total individuals at this growth stage were enumerated less than sapling. This was due to the cover of tree stand canopy limited of sunlight. Especially the shade-intolerant species. Swietenia mahagony was the highest density at 8 ind ha ${ }^{-}$ 1 , and also it's had the highest frequency and basal area. Consequently, it was the important species at poles level with the highest IVI at $58.47 \%$.

Species were found at seedling and sapling stages were rare or not found at all at pole stage. Total individuals were registered also more less. G. gnemon was the species that also could be found at sapling stage. It had the second highest IVI at $54.82 \%$.

\subsubsection{Trees}

here were 27 species determinate of 155 individuals at trees stage. Tectona grandis was the species with the highest density value at this stage there are 19 ind $\mathrm{ha}^{-1}$, followed by Dipterocarpus gracilis (15 ind ha ${ }^{-1}$ ) and Quercus sundaica (17 ind ha $\left.{ }^{-1}\right)$. T. grandis was also the important species with the highest IVI at $46.50 \%$ (Fig.1).

According to the sunlight tolerance, $T$. grandis, $Q$. sundaica and D. gracilis were shade-tolerant species at adult phase and shade-intolerant species at seedling phase, so they could grow optimally and become the dominant vegetation at there. At seedling and sapling stage, these three species were rare or not found in this study, but they found at the pole stage, even they could be died or languish before at tree stage.

Fig.1. IVI species were potentially to become the habitat (food source) for ebony leaf monkey.

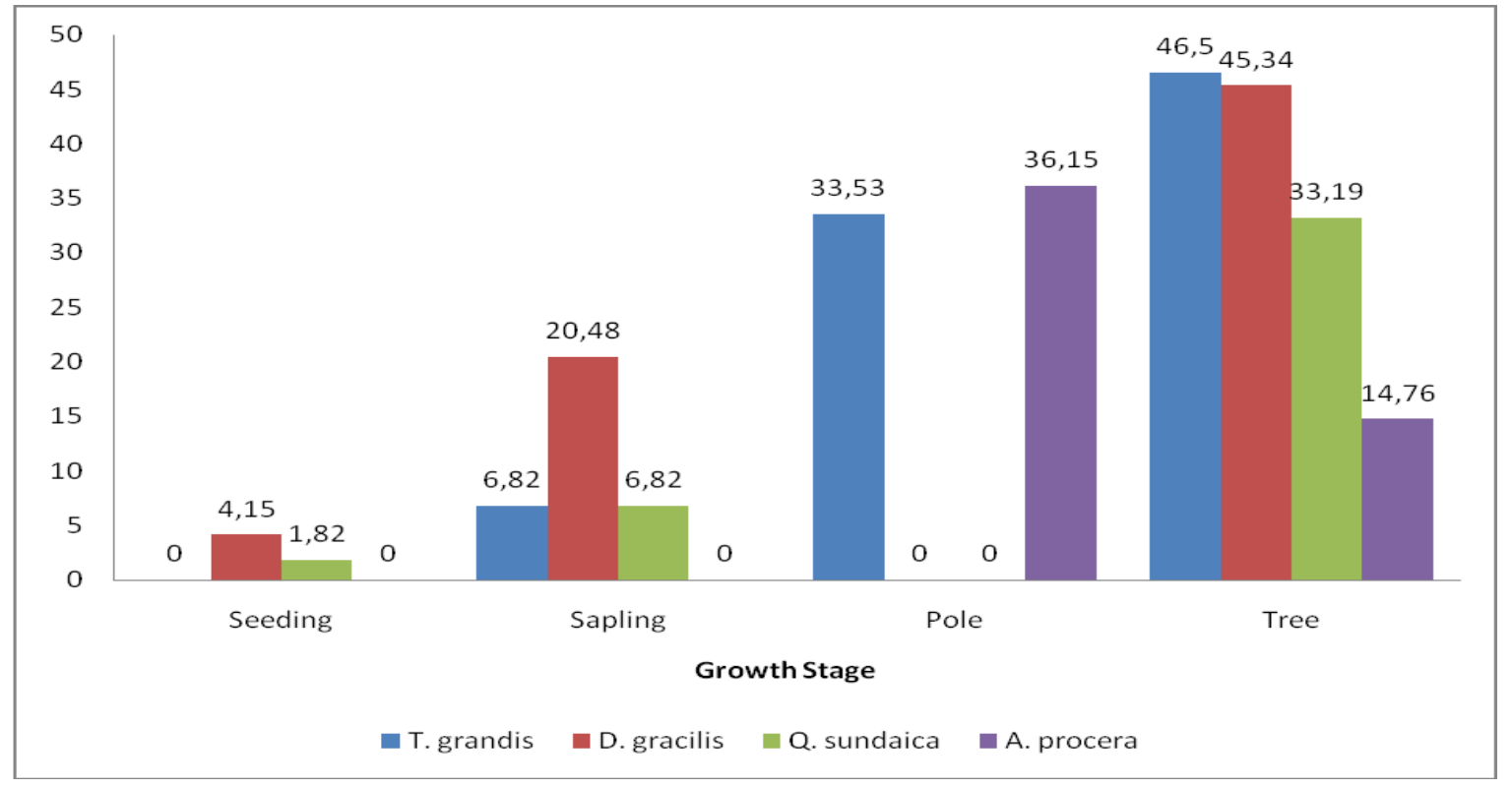

\subsection{Vegetation Composer Ebony Leaf Monkey's Habitat}

According to the vegetation analyze, the species of trees stage were potentially to become the habitat and food source for ebony leaf monkey were $T$. grandis, $D$. gracilis, Q. sundaica, Albizzia procera and Ficus superba. These species were found with high abundant at trees stage and they also had the high IVI, except $F$. superba. These value were $46.50 \%, 45.35 \%, 33.20 \%$ and $14.76 \%$ respectively. Besides those species, G. gnemon and $S$. mahagony were also potentially to become the habitat and food source for ebony leaf monkey. $G$. gnemon was dominant species at pole and sapling stage. The result of the IVI analysis were presented in figure.1.

These trees as ebony leaf monkey's habitat shows that they grow steadily in this ecosystem, but has not been able to maintain its existence (regeneration) since some of them were least successfully grown in their growth stage. At the tree level, T. Grandis had the highest relative frequency and relative diversity value, means it had existence (frequency and abundance) and also spreads more evenly than other species. However, this species was not found at seedling and sapling stages (consociation), it was a competition to grab and fight the same habitat. Due to the spatial and light competition.

In Kecubung Ulolanang Nature Preservation, ebony leaf monkey had many kinds of tree to be their habitat, although there was a little concern about the regeneration of these feed trees. 


\section{Conclusion}

The result were identify of 978 individuals belonging to 68 species of growth stage was registered in the 24 plots. There were 43 species of 772 individual at seedling stage including trees and shrubs, 18 species of 32 individuals at sapling stage, 8 species of 10 individuals at poles stage and 27 species at of 155 individuals at trees stage. The highest diversity index was found at seedling level (3.24), at tree level (3. 2). Furthermore, at sapling and pole level the diversity index were 2.64 and 2.02 respectively.

Moreover, species that had the highest important value index at seedling level was Stenochlaena palustri, at the sapling level was Gnetum gnemon, at pole level was Swietenia mahagoni and at tree level was Tectona grandis. The tree species of potentially to become habitat and food source for ebony leaf monkey were $T$. grandis, D. gracilis, Q. sundaica and F. superba.

\section{References}

1. V. Nijman, Contribution to Zoology.69(3), 157-177, (2000)
2. C. Roos, R. Boonratana, J. Supriatna, J.R. Fellowes, C.P. Groves, \& D. Stephen. Asian Primate Journal. 4 (1): 2-38, (2014)

3. E. Sulistyadi, PA. Kartono, I. Maryanto, Pergerakan Lutung Jawa Trachypithecus auratus (E. Geoffroy 1812) Pada Fragmen Habitat Terisolasi Di Taman Wisata Alam Gunung Pancar (Twagp) Bogor. Berita Biologi.12(3),383-395, (2013)

4. Q. Ayunin, S. Pudyatmoko, AM. Imron, Jurnal Penelitian Hutan dan Konservasi Alam. 11 No. 3 : 261-279, (2014)

5. J.B. Leca, N. Gunst, A. Rompis, G. Soma, I.G.A. Putra, I.N. Wandia, Primate Conservation Journal. 26: 133-144, (2013).

6. H. Gunawan, BL. Prasetyo, A. Mardiastuti, PA. Kaartono, Jurnal Penelitian Hutan dan Konservasi Alam. VII No.1 : 75-91, (2010)

7. BKSDA, Rencana Pengelolaan Cagar Alam di Kabupaten Batang. Not published, (2015)

8. C. Kusmana, Metode Survey Vegetasi. PT. Institut Pertanian Bogor. Bogor, (1997)

9. Mueller-Dombois, L.D. Ellenberg, H.1974. Aims and Methods of Vegetations Ecology. John Wiley \& Sons, Inc. New York. 